\title{
Neodymium(III) Hydroxide Coprecipitation- FAAS System for the Speciation of Chromium in Natural Waters
}

\author{
Mustafa Soylak* and Nebiye Kizil \\ Erciyes University, Faculty of Sciences, Chemistry Department \\ 38039 Kayseri, Turkey
}

\section{INTRODUCTION}

The speciation of metals in environmental samples is critical for assessing their potential environmental impact before disposal (1, 2). In particular, the accurate determination of different ionic species of elements at trace levels, such as $\mathrm{Cr}(\mathrm{III})$ and $\mathrm{Cr}(\mathrm{VI}), \mathrm{Sb}(\mathrm{III})$ and $\mathrm{Sb}(\mathrm{V})$, or $\mathrm{As}(\mathrm{III})$ and $\mathrm{As}(\mathrm{V})$, is very important because each ionic species has a different toxicology (3-6). Because of the different toxicology of $\mathrm{Cr}(\mathrm{III})$ and $\mathrm{Cr}(\mathrm{VI})$, the speciation study of chromium is very important $(7-10)$. $\mathrm{Cr}(\mathrm{VI})$ is more toxic than $\mathrm{Cr}(\mathrm{III})$, and $\mathrm{Cr}(\mathrm{VI})$ is carcinogenic and mutagenic to humans, animals, and plants (11-13).

The direct determination of metal ions with two oxidation states in the same samples, such as $\mathrm{Cr}(\mathrm{III})$ or $\mathrm{Cr}(\mathrm{VI})$, is not possible in atomic absorption spectrometric analysis (14-16). Generally, the first step in sample preparation includes the separation of the species from each other prior to atomic absorption spectrometric detection of the analytes for speciation. In the second step, total chromium is determined after reduction of $\mathrm{Cr}(\mathrm{VI})$ or oxidation of Cr(III) (17-20). Solid phase extraction, solvent extraction, cloud point extraction, and membrane filtration are the most widely used sample preparation techniques for the speciation of chromium species in environmental samples (15-20). The speciation of

*Corresponding author.

E-mail: soylak@erciyes.edu.tr

Fax: +903524374933

\section{ABSTRACT}

A new coprecipitation procedure is presented for the speciation of $\mathrm{Cr}$ (III) and $\mathrm{Cr}(\mathrm{VI})$ on neodymium(III) hydroxide precipitate. Chromium determination was performed by flame atomic absorption spectrometry. Total chromium was determined by application of the same procedure after reducing $\mathrm{Cr}(\mathrm{VI})$ to $\mathrm{Cr}$ (III). The concentration of Cr(VI) was calculated by the concentration difference between total $\mathrm{Cr}$ and $\mathrm{Cr}$ (III). The optimal parameters that affected the quantitative recoveries of Cr(III) were investigated. The influences of co-existing ions were controlled. The detection limit and preconcentration factor for Cr(III) were $2.1 \mu \mathrm{g} / \mathrm{L}$ and 100 , respectively. The method was applied to the speciation and determination of chromium in natural water samples.

chromium can also be performed using coprecipitation procedures (21-23) which are simple, rapid, and efficient techniques with a high preconcentration factor. The use of various hydroxides of the metals is popular for this purpose.

In this study, we used Nd(III) hydroxide precipitate for the coprecipitation and speciation of $\mathrm{Cr}$ (III) and $\mathrm{Cr}(\mathrm{VI})$. Various analytical parameters such as $\mathrm{pH}$, amount of $\mathrm{Nd}(\mathrm{III})$, sample volume, and matrix effects were optimized. The procedure was applied to the speciation of chromium in natural water samples.

\section{EXPERIMENTAL}

\section{Instrumentation}

The instrumental detection system used for this study was a PerkinElmer ${ }^{\circledR}$ Model 3110 flame atomic absorption spectrometer (PerkinElmer, Inc., Shelton, CT, USA), equipped with a chromium hollow cathode lamp operated at $25 \mathrm{~mA}$. The wavelength and spectral band pass were set at $357.9 \mathrm{~nm}$ and $0.7 \mathrm{~nm}$, respectively. A $10-\mathrm{cm}$ single-slot burner head and an airacetylene flame were used. The nebulizer uptake rate was adjusted to provide optimum response for conventional sample introduction resulting in $6.0 \mathrm{~mL} / \mathrm{min}$. An acetylene flow rate of $2.5 \mathrm{~L} / \mathrm{min}$ was used with an air flow rate of $17.0 \mathrm{~L} / \mathrm{min}$.

A pH meter, model Nel pH-900 (Ankara, Turkey), equipped with a glass electrode, was employed for measuring the $\mathrm{pH}$ values in the aqueous phase. Distilled/deionized water (Millipore ${ }^{\circledR}$ Milli- $\mathrm{Q}^{\mathrm{TM}}$ system) was used for preparation of the sample solutions.

\section{Reagents and Standard Solutions}

Analytical reagent-grade chemicals were employed for the preparation of all solutions. All laboratory glassware was kept overnight in a $10 \%(\mathrm{v} / \mathrm{v}) \mathrm{HNO}_{3}$ solution and then rinsed with deionized doubly distilled water. The Cr(III) and Cr(VI) stock solutions were prepared from $\mathrm{Cr}\left(\mathrm{NO}_{3}\right)_{3}$ in $0.5 \mathrm{~mol} \mathrm{~L}^{-1} \mathrm{HNO}_{3}$ and $\mathrm{K}_{2} \mathrm{CrO}_{4}$ in distilled water, respectively, with a concentration of $1000 \mathrm{mg} \mathrm{L}^{-1}$. A $0.1 \%$ solution of $\mathrm{Nd}$ (III) was prepared fresh daily by 
dissolving Nd(III) oxide (Suprapur ${ }^{\circledR}$ grade, E. Merck, Darmstadt, Germany) in small amounts of nitric acid and diluting to $50 \mathrm{~mL}$ with doubly distilled water (24). Diluted $\mathrm{NaOH}$ solutions ( $\left.1 \mathrm{~mol} \mathrm{~L}^{-1}\right)$ were used for $\mathrm{pH}$ adjustments.

The certified reference materials (CRMs) used were TMDA-53.3 Fortified Water (National Water Research Institute of Canada, Burlington, ON, Canada) and SPSWW2 Wastewater Level 2 (Spectrapure Standards AS, Oslo, Norway).

\section{Procedure for Speciation}

A solution of $20-30 \mathrm{~mL}$, containing $20 \mu \mathrm{g}$ of $\mathrm{Cr}$ (III) and $1.0 \mathrm{mg}$ of $\mathrm{Nd}(\mathrm{III})$, was used. The $\mathrm{pH}$ was adjusted to the desired value by addition of $1 \mathrm{~mol} \mathrm{~L}^{-1} \mathrm{NaOH}$ solution. The solution was centrifuged at $2500 \mathrm{rpm}$ for 10 minutes and the supernatant removed. The Nd(III) hydroxide precipitate adhering to the tube was dissolved with $1 \mathrm{~mL}$ of $1 \mathrm{~mol} \mathrm{~L}^{-1} \mathrm{HNO}_{3}$ and its final volume was completed to $10.0 \mathrm{~mL}$ with distilled water.

The reduction for $\mathrm{Cr}(\mathrm{VI})$ to Cr(III) was performed by using the procedure given in the literature $(25,26)$. An amount of $0.5 \mathrm{~mL}$ con- centrated sulphuric acid and $0.5 \mathrm{~mL}$ ethanol was added to the model solution. After reduction of Cr(VI) to $\mathrm{Cr}$ (III), the method described above was applied to the determination of total $\mathrm{Cr}$. The level of Cr(VI) was calculated by the difference between the total chromium and $\mathrm{Cr}$ (III) concentrations.

\section{Application to Real Samples}

TMDA-53.3 Fortified Water or SPS-WW2 Wastewater Level 2 certified reference material was used directly and the coprecipitation procedure given above applied after adjusting the $\mathrm{pH}$ to 10.0 with $1 \mathrm{~mol} \mathrm{~L}^{-1} \mathrm{NaOH}$ solution.

The proposed method was applied to natural water samples including a tap water from Erciyes University and water from a well at Kayseri. The water samples analyzed were collected in pre-washed polyethylene bottles. Before analysis, the $\mathrm{pH}$ of the water samples was adjusted to 10.0 with $1 \mathrm{~mol} \mathrm{~L}^{-1}$ $\mathrm{NaOH}$ solution. The coprecipitation procedure discussed above was applied and the chromium levels were determined using the flame atomic absorption spectrometer.

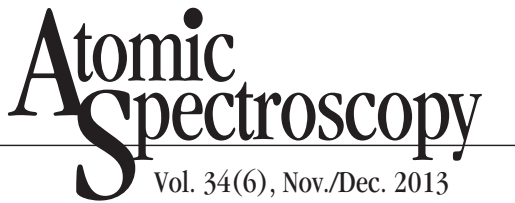

\section{RESULTS AND DISCUSSION}

\section{Optimization}

In the coprecipitation of metal ions with hydroxide precipitates, the $\mathrm{pH}$ of the working media is generally basic (27-29). The effect of $\mathrm{pH}$ on the precipitation-separation efficiency of both chromium species was examined separately in the range of 7.0-12.0 by adjustment with $1 \mathrm{~mol} \mathrm{~L}^{-1} \mathrm{NaOH}$ (Figure 1). The recoveries of $\mathrm{Cr}$ (III) were quantitative (>95\%) in the working $\mathrm{pH}$ range, while the recovery of Cr(VI) was lower than 7\%. In light of these results, it is possible to separate $\mathrm{Cr}(\mathrm{III})$ from $\mathrm{Cr}(\mathrm{VI})$ in the $\mathrm{pH}$ range of 7.0-12.0. Thus, $\mathrm{pH} 10$ was selected for further studies.

The influence of amount of neodymium on the recovery values of $\mathrm{Cr}$ (III) was investigated in the range of $0.5-3.0 \mathrm{mg}$ at $\mathrm{pH} 10.0$ (Figure 2). The recovery values increased and reached quantitative values in the range of $1.0-3.0 \mathrm{mg}$ $\mathrm{Nd}(\mathrm{III})$. Thus, the use of $\mathrm{Nd}(\mathrm{III})$ hydroxide makes quantitative separation of $\mathrm{Cr}$ (III) feasible. The optimum amount of $1.0 \mathrm{mg}$ of $\mathrm{Nd}$ (III) was selected for all further studies.

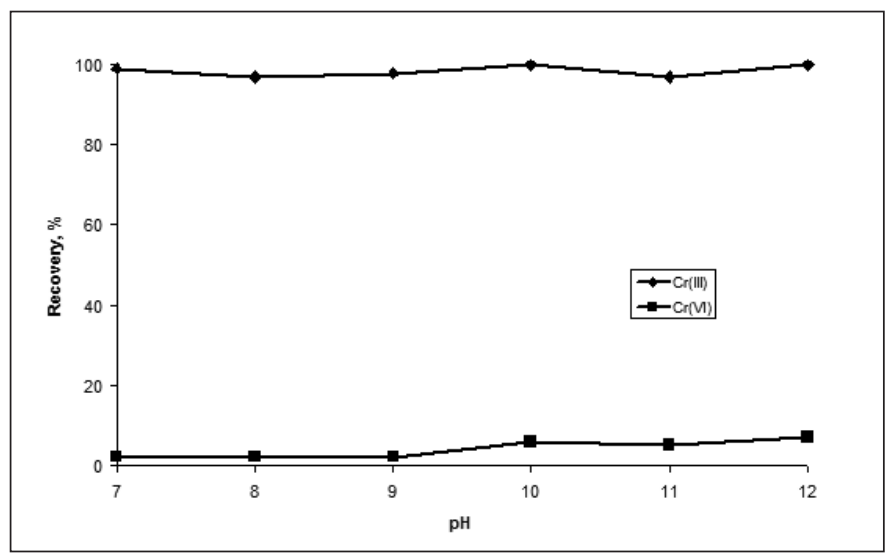

Fig. 1. The relation of recovery of chromium species and $p H$ $(N=3)$.

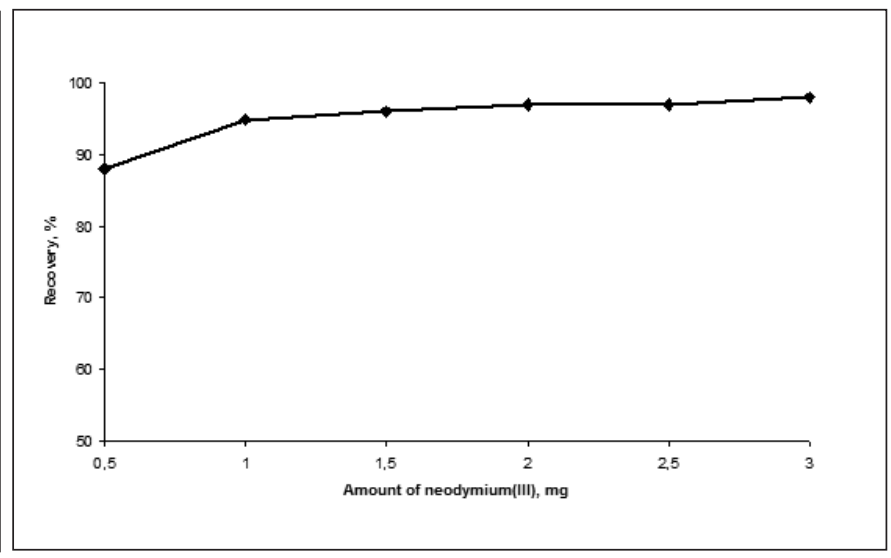

Fig. 2. Effect of $\mathrm{Nd}(\mathrm{III})$ amount on the recovery of Cr(III) $(N=3)$. 
The standing time was examined in the range of $0-30$ minutes due to the formation of a precipitate (Table I). Quantitative recovery values were obtained after 5 minutes of standing time and were selected for this study.

TABLE I

Influences of Standing Time on the Recoveries of $\mathrm{Cr}$ (III) $(\mathrm{N}=3)$

\begin{tabular}{cc}
\hline $\begin{array}{c}\text { Standing Time } \\
\text { (min.) }\end{array}$ & $\begin{array}{c}\text { Recovery } \\
(\%)\end{array}$ \\
\hline 0 & $92 \pm 2^{\mathrm{a}}$ \\
5 & $97 \pm 2$ \\
10 & $98 \pm 1$ \\
20 & $98 \pm 1$ \\
30 & $97 \pm 2$ \\
\hline
\end{tabular}

${ }^{\mathrm{a}}$ Mean \pm standard deviation.

TABLE II

Relationship Between

Centrifugation Speed and Recovery of Cr(III)

\begin{tabular}{cc}
\hline $\begin{array}{c}\text { Centrifugation } \\
\text { Speed (rpm) }\end{array}$ & $\begin{array}{c}\text { Recovery } \\
(\%)\end{array}$ \\
\hline 1000 & $79 \pm 3^{\mathrm{a}}$ \\
1500 & $89 \pm 2$ \\
2000 & $93 \pm 2$ \\
2500 & $95 \pm 1$ \\
3000 & $97 \pm 3$ \\
3500 & $98 \pm 1$ \\
4000 & $98 \pm 2$
\end{tabular}

${ }^{\mathrm{a}}$ Mean \pm standard deviation.

TABLE III

Influence of Centrifugation

Time on the Recoveries of Cr(III)

\begin{tabular}{cc}
\hline $\begin{array}{c}\text { Centrifugation } \\
\text { Time (min) }\end{array}$ & $\begin{array}{c}\text { Recovery } \\
(\%)\end{array}$ \\
\hline 2 & $88 \pm 3^{\mathrm{a}}$ \\
5 & $95 \pm 2$ \\
10 & $95 \pm 1$ \\
20 & $97 \pm 1$ \\
30 & $99 \pm 1$ \\
\hline
\end{tabular}

${ }^{\mathrm{a}}$ Mean \pm standard deviation.
The effects of centrifugation speed on the recoveries of $\mathrm{Cr}$ (III) were studied in the range of 1000-4000 rpm (Table II). Quantitative values were obtained in the range of 2500-4000 rpm. Thus, the centrifugation speed of $2500 \mathrm{rpm}$ was used for all further work.

The influence of centrifugation time on the present neodymium hydroxide coprecipitation system for $\mathrm{Cr}(\mathrm{III})$ was studied in the range of 2-30 minutes (Table III). The recovery values were quantitative in the time range of 5-30 minutes. The optimum value of 10 minutes was selected for this study.

To improve the preconcentration factor, the sample volume of the working media is a key factor in preconcentration studies for metal ions (30-35). The effects of sample volume on the recoveries of $\mathrm{Cr}$ (III) in the neodymium hydroxide coprecipitation system were investigated in the $20-1000 \mathrm{~mL}$ range. The results in Figure 3 show that Cr(III) was quantitatively recovered at all working ranges of the sample volume and a preconcentration factor of 100 was obtained (sample volume: $1000 \mathrm{~mL}$, final volume: $10 \mathrm{~mL}$ ).

\section{Effects of Concomitants}

It is known that concomitant ions present at the $\mu \mathrm{g} / \mathrm{mL}$ level in natural waters influence the determination of metal ions by atomic absorption spectrometry (36-44), The effects of some alkaline, alkaline earth, transition metals, and some anions on the recovery of Cr(III) were investigated and the results are summarized in Table IV. Since the recovery values for Cr(III) are generally quantitative in the presence of the investigated concomitant ions, it was found that the coprecipitation method can be applied to the analysis of natural water samples.

\section{Total Cr}

For the determination of total $\mathrm{Cr}$, model solutions containing different amounts of $\mathrm{Cr}$ (VI) and $\mathrm{Cr}$ (III) were prepared (Table V). The reduction of $\mathrm{Cr}(\mathrm{VI})$ ions to $\mathrm{Cr}$ (III) was performed $(25,26)$ and the procedure proposed was applied to these solutions. The results in Table V show that the coprecipitation method can also be applied for the determination of total chromium in aqueous samples.

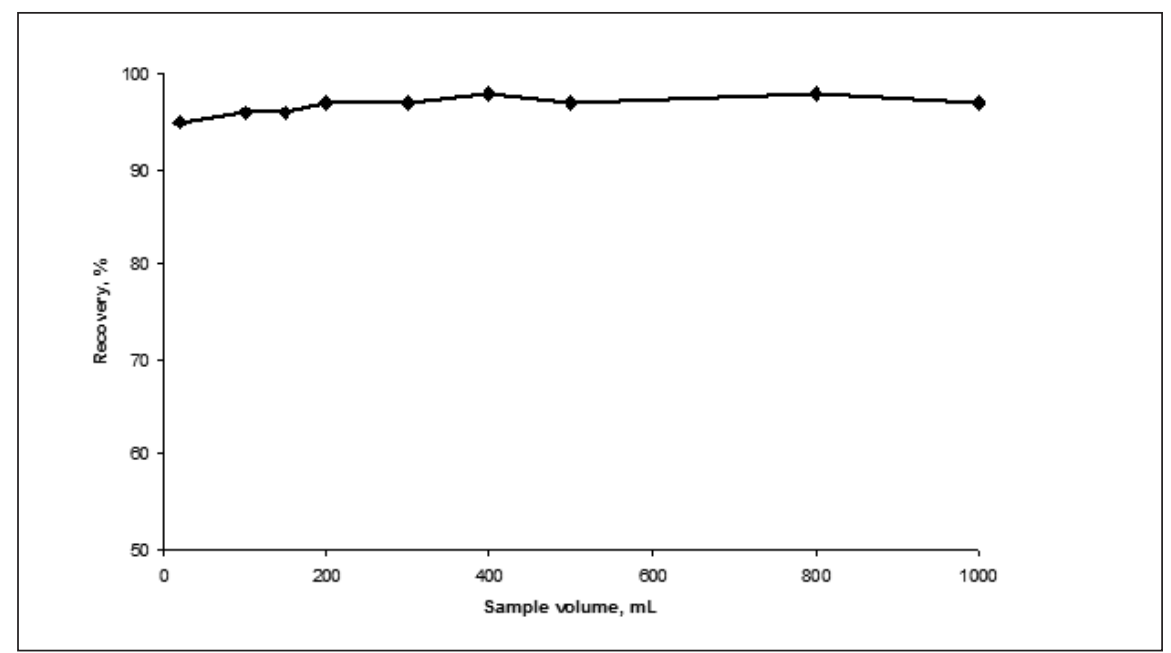

Fig. 3. The influence of sample volume $(N=3)$. 


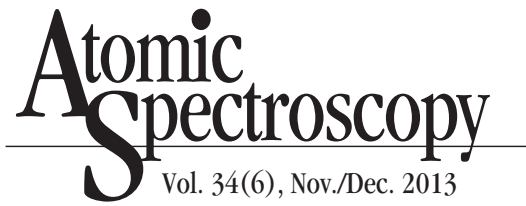

TABLE IV

Influences of Concomitant Ions on the Recoveries of Cr(III)

\begin{tabular}{lcc}
\hline $\begin{array}{c}\text { Con } \\
\text { comitant }\end{array}$ & $\begin{array}{c}\text { Concen- } \\
\text { tration } \\
(\mu \mathrm{g} / \mathrm{mL})\end{array}$ & $\begin{array}{c}\text { Recovery } \\
(\%)\end{array}$ \\
\hline $\mathrm{Mg}^{2+}$ & 3000 & $100 \pm 2^{\mathrm{a}}$ \\
$\mathrm{K}^{+}$ & 5000 & $95 \pm 3$ \\
$\mathrm{Ca}^{2+}$ & 3000 & $95 \pm 2$ \\
$\mathrm{Na}^{+}$ & 7000 & $97 \pm 1$ \\
$\mathrm{SO}_{4}^{2^{2-}}$ & 2000 & $97 \pm 1$ \\
$\mathrm{Cl}^{-}$ & 5000 & $100 \pm 1$ \\
$\mathrm{Fe}^{3+}$ & 20 & $98 \pm 2$ \\
$\mathrm{Al}^{3+}$ & 20 & $100 \pm 1$ \\
$\mathrm{Cu}^{2+}$ & 20 & $98 \pm 2$ \\
$\mathrm{Ni}^{2+}$ & 20 & $98 \pm 3$ \\
$\mathrm{Co}^{2+}$ & 10 & $95 \pm 2$ \\
$\mathrm{Cd}^{2+}$ & 10 & $100 \pm 1$ \\
\hline
\end{tabular}

${ }^{\mathrm{a}}$ Mean \pm standard deviation.

\section{Performance of the Method}

The detection limit, defined as the concentration equivalent to three times the standard deviation $(\mathrm{N}=20)$ of the reagent blank, was $2.1 \mu \mathrm{g} / \mathrm{L}$. The precision of the present enrichment method, calculated as the relative standard deviation of the measurements carried out with the sample solutions $(\mathrm{N}=10)$, was below $5.0 \%$.

\section{Analysis of Real Samples}

The proposed coprecipitation method was applied to two certified water reference materials (TMDA-53.3 Fortified Water and SPS-WW2 Wastewater Level 2). The results given in Table VI show good agreement with the certified values for chromium.

The coprecipitation method was also applied to the speciation of $\mathrm{Cr}(\mathrm{III})$ and $\mathrm{Cr}(\mathrm{VI})$ in natural water samples: well water and tap water. Chromium species were also spiked to these samples. The results listed in Table VII show that there is good agreement between the added and measured analyte amounts.
TABLE V

Determination of Total Chromium in Spiked Test Solutions $(\mathrm{N}=3)$

\begin{tabular}{ccccc}
\hline \multicolumn{2}{c}{ Added $(\mu \mathrm{g})$} & \multicolumn{2}{c}{ Found $(\mu \mathrm{g})$} & Calculated $(\mu \mathrm{g})$ \\
$\mathrm{Cr}(\mathrm{III})$ & $\mathrm{Cr}(\mathrm{VI})$ & $\mathrm{Cr}(\mathrm{III})$ & Total $\mathrm{Cr}$ & $\mathrm{Cr}(\mathrm{VI})$ \\
\hline 0 & 25 & - & $24.5 \pm 0.5$ & - \\
5 & 20 & $4.8 \pm 0.5^{\mathrm{a}}$ & $24.5 \pm 0.5$ & $19.7 \pm 1$ \\
12.5 & 12.5 & $11.7 \pm 1.0$ & $24.5 \pm 0.5$ & $12.8 \pm 1$ \\
20 & 5 & $19.0 \pm 1.0$ & $24.5 \pm 0.5$ & $5.5 \pm 0.5$ \\
25 & 0 & $24.5 \pm 1.0$ & $24.5 \pm 0.5$ & - \\
\hline
\end{tabular}

${ }^{\mathrm{a}}$ Mean \pm standard deviation.

TABLE VI

Application of Proposed Method for Chromium Determination in Certified Reference Materials $(\mathrm{N}=3)$

\begin{tabular}{lccc}
\hline & $\begin{array}{c}\text { Certified } \\
\text { value } \\
(\mu \mathrm{g} / \mathrm{L})\end{array}$ & $\begin{array}{c}\text { Found by } \\
\text { present method } \\
(\mu \mathrm{g} / \mathrm{L})\end{array}$ & $\begin{array}{c}\text { Recovery } \\
(\%)\end{array}$ \\
\hline TMDA-53.3 Fortified Water & 340 & $337 \pm 1^{\mathrm{a}}$ & 99 \\
SPS-WW2, Wastewater Level 2 & 1000 & $1050 \pm 32$ & 105 \\
\hline
\end{tabular}

${ }^{\mathrm{a}}$ Mean \pm standard deviation.

TABLE VII

Application of the Presented Method to Water Samples (N=3)

Well Water

\begin{tabular}{ccccc}
\multicolumn{2}{c}{ Added $(\mu \mathrm{g})$} & \multicolumn{2}{c}{ Found $(\mu \mathrm{g})$} & Calculated $(\mu \mathrm{g})$ \\
\hline $\mathrm{Cr}(\mathrm{III})$ & $\mathrm{Cr}(\mathrm{VI})$ & $\mathrm{Cr}(\mathrm{III})$ & Total $\mathrm{Cr}$ & $\mathrm{Cr}(\mathrm{VI})$ \\
\hline 0 & 0 & $\mathrm{BDL}^{\mathrm{a}}$ & - & - \\
15 & 15 & $14.1 \pm 1.0$ & $28.2 \pm 1.0$ & $14.1 \pm 0.5$ \\
30 & 0 & $28.9 \pm 1.0$ & $28.9 \pm 1.0$ & - \\
\hline
\end{tabular}

Tap Water

\begin{tabular}{ccccc}
\multicolumn{2}{c}{ Added $(\mu \mathrm{g})$} & \multicolumn{2}{c}{ Found $(\mu \mathrm{g})$} & Calculated $(\mu \mathrm{g})$ \\
\hline $\mathrm{Cr}(\mathrm{III})$ & $\mathrm{Cr}(\mathrm{VI})$ & $\mathrm{Cr}(\mathrm{III})$ & Total $\mathrm{Cr}$ & $\mathrm{Cr}(\mathrm{VI})$ \\
\hline 0 & 0 & $\mathrm{BDL}^{\mathrm{a}}$ & - & - \\
0 & 25 & - & $24.3 \pm 1.0$ & - \\
5 & 20 & $4.8 \pm 0.5$ & $24.4 \pm 1.1$ & $19.4 \pm 0.5$ \\
12.5 & 12.5 & $12.1 \pm 1.0$ & $24.3 \pm 1.0$ & $12.2 \pm 1$ \\
20 & 5 & $19.4 \pm 1.0$ & $24.2 \pm 1.0$ & $4.8 \pm 0.5$ \\
25 & 0 & $24 \pm 2.0$ & $24.3 \pm 1.0$ & -
\end{tabular}

${ }^{\mathrm{a}} \mathrm{BDL}=$ Below detection limit. 


\section{CONCLUSION}

A new coprecipitation procedure has been presented by speciation of $\mathrm{Cr}(\mathrm{III})$ and $\mathrm{Cr}(\mathrm{VI})$ on neodymium(III) hydroxide precipitate. The optimum parameters that affected the quantitative recoveries of $\mathrm{Cr}$ (III) were investigated. The influences of coexisting ions were controlled and the detection limit for $\mathrm{Cr}$ (III) was found at $2.1 \mu \mathrm{g} / \mathrm{L}$. The advantages of the present method include high salt tolerance, high preconcentration factor for $\mathrm{Cr}$ species, and applicability of the method to both oxidation states of $\mathrm{Cr}$. The precision and accuracy of the method was satisfactory. The developed method is especially suitable for the determination of chromium species in natural water samples.

\section{ACKNOWLEDGMENT}

The authors are grateful for the financial support of the Unit of the Scientific Research Project of Erciyes University, Turkey.

\section{Received June 10, 2013.}

\section{REFERENCES}

1. P. Venkateswaran, S. Vellaichamy and K. Palanivelu, Int. J. Environ. Sci. Techn. 4, 497 (2007).

2. I. Narin, A. Kars and M. Soylak, J. Hazard. Mater. 150, 453 (2008).

3. Y.J. Li, B. Hu, M. He and G.Q. Xiang, Water Res. 42, 1195 (2008).

4. N. Ozdemir, M. Soylak, L. Elci and M. Dogan, Anal. Chim. Acta. 505, 37 (2004).

5. M. Díaz-Pérez, M. Aboal-Somoza, $P$. Bermejo-Barrera and A. BermejoBarrera, Spectrosc. Lett. 44, 17 (2011).

6. M. Tuzen, D. Citak, D. Mendil and M. Soylak, Talanta, 78, 52 (2009).

7. K.O. Saygi, M. Tuzen, M. Soylak and L. Elci, J. Hazard. Mater. 153, 1009 (2008).
8. K. Oktor, S. Yilmaz, G. Turker and E. Erkus, Environ. Monit. Assess. 141, 97 (2008).

9. Y, Furusho, M, Ono, M, Yamada, T, Kitade and S. Motomizu, Bunseki Kagaku 58, 147 (2009).

10. J.C. Yu, X.J. Wu and Z.L. Chen, Anal. Chim. Acta. 436, 59 (2001).

11. E. Vassileva, K. Hadjiivanov, T. Stoychev and C. Daiev, Analyst 125, 693 (2000).

12. M. Soylak, S. Saracoglu, U. Divrikli and L. Elci, Environ. Monit. Assess. 127, 169 (2007).

13. M.S. El-Shahawi, H.M. Al-Saidi, A.S. Bashammakh, A.A. Al-Sibaai and M.A. Abdelfadeel, Talanta 84, 175 (2011).

14. M. Soylak, Quim. Anal. 20, 175 (2002).

15. B. Demirata, Mikrochim. Acta. 136, 143 (2001).

16. U. Divrikli, M. Soylak and L. Elci, Environ. Monit. Assess. 138, 167 (2008).

17. D. Bantrjee and A.K. Das, J. Indian Chem. Soc. 83, 479 (2006).

18. A. Karatepe, E. Korkmaz, M. Soylak and L. Elci, J. Hazard. Mater. 173, 433 (2010).

19. P. Liang and J. Li, At. Spectrosc. 26, 89 (2005).

20. M. Tuzen, O.D. Uluozlu and M. Soylak, J. Hazard. Mater. 144, 549 (2007).

21. M.C. Mehra and A.S. Guimond, Asian J. Chem. 11, 409 (1999).

22. F. Aydin and M. Soylak, J. Hazard. Mater. 162, 1228 (2009).

23. J. Ueda, H. Satoh and S. Kagaya, Anal. Sci. 13, 613 (1997).

24. M. Soylak and N. Kizil, J. AOAC Int. 94, 978 (2011).

25. M. Tuzen and M. Soylak, J. Hazard. Mater. 129, 266 (2006).

26. M. Soylak, E. Yilmaz and S. Saracoglu, Curr. Anal. Chem. 8, 358 (2012).

27. M. Soylak and A. Aydin, J. Iran. Chem. Soc. 9, 263 (2012).

28. F.A. Aydin and M. Soylak, Talanta, 73, 134 (2007).
29. S. Saracoglu, M. Soylak and L. Elci, Trace Elem. Electroly. 18, 129 (2001).

30. Y.P. de Peña, W. Rondón and P Carrero, Avances Quím. 5, 79 (2010)

31. M. Soylak and M. Tuzen, J. Hazard. Mater. 152, 656 (2008).

32. A. Islam, M.A. Laskar and A. Ahmad, Environ. Monit. Assess. 175, 201 (2011).

33. M. Soylak, U. Sahin and L. Elci, Anal. Chim. Acta. 322, 111 (1996)

34. G. Ferreira, R.S.D. Laercio Caetano, P.M. Castro and G.R. Castro, Clean. Techn. Environ. Policy 13, 397 (2011).

35. S. Saracoglu, M. Soylak, D. Cabuk, Z. Topalak, Y. Karagozlu, J. AOAC Int., 95, 892 (2012).

36. D. Ozdes, C. Duran, H. Bektas, M. Tufekci, and M. Soylak, Spectrosc. Lett., 45, 330 (2012).

37. M. Soylak, A.U. Karatepe, L. Elci, and M. Dogan, Turk. J. Chem. 27, 235 (2003).

38. F. Sabermahani, M.A. Taher, H. Bahrami, and S. Fozooni, J. Hazard. Mater. 185945 (2011).

39. M. Soylak, Anal. Lett., 37, 1203 (2004).

40. C.P. Mane and M.A. Anuse, J. Chinese Chem. Soc. 55, 807 (2008).

41. L. Elci, M. Soylak, A. Uzun, E. Buyukpatir, and M. Dogan, Fresenius J. Anal. Chem., 368, 358 (2000).

42. H. Abdolmohammad-Zadeh and E. Ebrahimzadeh, J. Braz. Chem. Soc. 22, 517 (2011).

43. M. Soylak, L. Elci, and M. Dogan, Asian J. Chem. 15, 1735 (2003).

44. I. Narin and M. Soylak, Fresenius Environ. Bull. 8, 24 (1999). 